\title{
PLANTATIO ECCLESIAE DAN PAROKI MISIONER DALAM ARDAS KEUSKUPAN SURABAYA 2020-2030
}

\author{
Petrus Canisius Edi Laksito \\ STKIP Widya Yuwana \\ edilaksito@widyayuwana.ac.id
}

\begin{abstract}
Plantatio Ecclesiae is a particular term elaborated in missiology in the first half of the $20^{\text {th }}$ century, and then used by the Vatican Council II in the decree on the mission activity of the Church Ad Gentes (1965) to designate the definition of mission and its goal, as well. From this perspective, it is believed that mission is not merely a question about converting souls and, therefore, bringing them to eternal salvation, but especially a "plantation of the Church" in the lands not yet touched by christian faith. Thus, mission is not only about individual salvation, but particularly about the formation of new Christian communities comprised of indigenous people with their own hierarchical leaders, who live their own native values and culture contributing themselves for the local development and the good of their own society, enlightened by christian faith and strengthened by christian love. Being used to determine the ideal of a missionary parish in the Basic Orientation (Arah Dasar) of the Diocese of Surabaya 2020-2030, this term is important to be studied. This study tries to learn how the ideal of a missionary parish, seen from the perspective of plantatio Ecclesiae theology, could be realized by the Catholic Church of the Diocese of Surabaya in the years to come.
\end{abstract}

Keywords: Plantatio Ecclesiae; parish; missionary; Diocese of Surabaya.

\section{PENDAHULUAN}

Ardas Keuskupan Surabaya 2020-2030 menjabarkan gagasan “persekutuan” ke dalam 12 butir penjelasan. Ke-12 butir tersebut membahas: dasar-dasar teologis persekutuan (B.1.-B.5.); hidup sakramental (B.6.-B.8.) dan spiritual (B.9.-B.10.) untuk membangun persekutuan; serta arah paroki sebagai persekutuan berbasis lingkungan di tengah masyarakat (B.11.) yang mengemban tugas misioner (B.12.).

Tulisan ini ingin menggali butir B.12. terkait tugas misioner: “Bertanggung Jawab Untuk Mewujudkan Plantatio Ecclesiae”. Subjek tanggung jawab mewujudkan plantatio Ecclesiae ("penanaman Gereja”) adalah paroki sebagai persekutuan yang dewasa. Kalimat pertama penjelasan butir tersebut 
menyatakan: "Kehadiran dan peran paroki yang semakin dewasa sangat penting untuk mewujudkan 'penanaman Gereja' (Plantatio Ecclesiae) di wilayah Keuskupan Surabaya.”

Plantatio Ecclesiae adalah istilah misiologi abad ke-20. Para teolog plantatio Ecclesiae memahami misi bukan sebagai upaya mempertobatkan dan menyelamatkan jiwa-jiwa, tapi terlebih "menanamkan Gereja” di dunia yang belum tersentuh iman kristiani. Konsep plantatio Ecclesiae mengaitkan misi bukan dengan keselamatan individu-individu, tapi dengan Gereja dan perkembangannya di seluruh di dunia.

Istilah plantatio Ecclesiae muncul dalam Dekret Konsili Vatikan II Ad Gentes (1965) untuk memberi orientasi bagi kegiatan misi Gereja kepada bangsabangsa. Di situ, istilah ini menjadi kunci untuk menjelaskan definisi dan tujuan misi.

Agar penggalian makna Ardas 2020-2030 butir B.12. ini berjalan baik, akan digali lebih dahulu makna plantatio Ecclesiae atau "penanaman Gereja" dari studi misiologi, dan penggunaannya dalam Ad Gentes. Rujukan pada dokumen Gereja ini penting karena Ardas sendiri merupakan arahan pastoral, sehingga perlu dibaca dengan merujuk pada dokumen Gereja di bidang yang bersangkutan.

Istilah plantatio Ecclesiae juga terdapat dalam Ardas 2020-2030 butir E.3., “Siap sedia menjadi pekerja misi”. Penjelasan butir tersebut menyatakan, untuk tersedianya pekerja-pekerja misi, program pembinaan pekerja misi perlu dikembangkan. Juga, “program penanaman Gereja (plantatio Ecclesiae) di daerah/wilayah di mana Kristus belum dikenal atau di daerah/wilayah di mana iman kepada-Nya telah memudar perlu dibangkitkan.” Maka di sini butir E.3. tentang pembinaan pekerja misi dan "pembangkitan kembali program penanaman Gereja” juga diperhatikan.

Tulisan ini ditutup dengan saran demi mewujudkan plantatio Ecclesiae melalui peran paroki sebagai persekutuan murid-murid Kristus yang memiliki tanggung jawab misioner seperti dikehendaki Ardas. Saran ini disusun dengan memperhatikan situasi, kondisi dan potensi umat, serta arah karya pastoral keuskupan di masa depan.

\section{PEMBAHASAN}

\subsection{Plantatio Ecclesiae dalam Studi Misiologi}

Misi Gereja berlangsung sejak Yesus yang bangkit memberikan tugas itu kepada para rasul. Tugas itu terlaksana melalui aneka tahap sejarah. Pada milenium pertama: dari periode penganiayaan sampai kebebasan dan penerimaan jemaat kristiani dalam masyarakat politik lewat Edik Milan (313), hingga dihasilkan benua Eropa kristiani. Pada milenium kedua, karya misi berangsur meluas, dari Eropa ke seluruh dunia, sesuai konteks dan tantangan zaman. Dari 
misi abad pertengahan hingga modern. Seiring munculnya kolonialisme: dari patronase raja-raja Portugal (1493) dan Spanyol (1508), disusul periode kemandirian organisasi misi kepausan lewat Kongregasi de Propaganda Fide (1622), hingga masuk era baru: kemerdekaan koloni-koloni di Asia dan Afrika, khususnya setelah Perang Dunia II (1945).

Refleksi Konsili Vatikan II (1965) tentang hakikat Gereja yang misioner dan misi Gereja kepada bangsa-bangsa dalam Ad Gentes merupakan buah penting perjalanan ini. Sebagai persidangan universal para uskup dalam kesatuan dengan paus, refleksi yang dihasilkan juga merupakan buah refleksi universal, melibatkan para ahli, aneka gerakan, kongregasi dan pusat studi yang memberi perhatian pada misi. Juga tidak kurang sumbangan refleksi Gereja-gereja lokal yang tumbuh dan berkembang sebagai buah karya misi di seluruh dunia. Dari proses itu dihasilkan dokumen penting ini, yang memberikan arah bagi karya misi Gereja selanjutnya.

Ad Gentes merumuskan tujuan misi sebagai berikut: "Tujuan khas kegiatan misioner itu mewartakan Injil dan menanamkan Gereja di tengah bangsabangsa atau golongan-golongan, tempat Gereja belum berakar” (art. 6). Di sini dipakai istilah “menanamkan Gereja”, atau dalam teks Latin plantatio Ecclesiae.

Pada kalimat sebelumnya, Ad Gentes mendefinisikan misi juga menggunakan gagasan “penanaman Gereja”. Menurut Ad Gentes, misi adalah:

"Prakarsa-prakarsa khusus, yang ditempuh oleh para pewarta Injil utusan Gereja dengan pergi keseluruh dunia untuk menunaikan tugas menyiarkan Injil dan menanamkan Gereja diantara para bangsa atau golongan-golongan yang belum beriman akan Kristus”.

Istilah “menanamkan Gereja”, atau plantatio Ecclesiae, dalam misiologi berakar pada Kitab Suci dan tradisi Gereja. Istilah ini pada abad ke-20 dipakai oleh pusat studi misi di Leuven, Belgia, dipelopori oleh Rm. Pierre Charles, SJ (1883-1954), sebagai istilah teknis, untuk mendefinisikan misi Gereja, yang sejak sebelum Perang Dunia I telah gencar dilakukan ke seluruh dunia.

Konsep plantatio Ecclesiae meletakkan misi dalam bingkai jatidiri Gereja. Misi, dalam teologi ini, adalah ungkapan diri Gereja, yang hakikatnya misioner. Dalam konsep ini, Gereja dipahami sebagai misteri yang dihadirkan Allah bagi keselamatan manusia dan diwujudkan dalam diri Kristus, "Sabda yang menjadi manusia”. Gereja adalah sakramen, sarana, kepanjangan atau kelanjutan peristiwa inkarnasi, yang mengantar seluruh umat manusia pada keselamatan dalam persatuan dengan Allah. Jatidiri Gereja yang melekat pada misteri inkarnasi mendasari hakikat Gereja yang misioner. Berbagai kegiatan misi dan pengembangan Gereja ke berbagai bangsa harus diletakkan dalam kerangka jatidiri ini (Insero, 2007: 115-120). 
Tugas mewujudkan keselamatan seluruh umat manusia lewat persatuan dengan Allah dalam Gereja, selain membentuk karakter misioner, juga mendasari prinsip katolisitas Gereja. Prinsip katolisitas tampak dalam sifat dan upaya kehadiran Gereja yang universal, terbuka dan tertuju kepada segala bangsa. Berbagai sarana dan karya misi Gereja serta keterlibatan para warganya di berbagai belahan dunia merupakan bagian dari upaya kehadiran universal menyelamatkan ini.

Agar keselamatan dalam persatuan dengan Allah sungguh dialami oleh umat manusia dari berbagai bangsa, di samping pewartaan Injil, misionaris mengupayakan kegiatan-kegiatan nyata mewujudkan nilai-nilai Injil dalam kehidupan sosial-budaya masyarakat atau bangsa setempat. Di tengah masyarakat semacam inilah, dibangun dan ditanam Gereja-gereja lokal, yaitu komunitas beriman bangsa setempat. Inilah arti plantatio Ecclesiae atau penanaman Gereja, sebagai realisasi universalitas dan katolisitasnya di tengah bangsa-bangsa, secara kultural, sosial, dan institusional.

Berdasar konsep tersebut, teologi plantatio Ecclesiae tidak sekedar bicara tentang Gereja yang "mempunyai kegiatan dan karya-karya” misi, tetapi Gereja yang “pada hakikatnya” berciri misioner. Di sini, misi tidak dipahami sebagai “suatu karya” tetapi sebagai “cara berada”, sebagai karakter yang melekat pada pribadi. Dalam perspektif Gereja yang misioner ini, komunitas-komunitas kristiani berupaya membentuk diri menjadi komunitas misioner, yang aktif berperan menghadirkan keselamatan Kristus dan nilai-nilai Injil-Nya dalam kehidupan sosial masyarakatnya.

Dari perspektif sosial dan eklesiologis ini, misi tidak sekedar dipahami sebagi urusan penyelamatan orang-orang non-kristiani, tapi terlebih sebagai pembentukan (formatio) Gereja dan penghadirannya di tengah bangsa-bangsa. Nota bene, gagasan misi sebagai penyelamatan jiwa-jiwa melatarbelakangi berbagai karya misi Gereja periode sebelumnya, khususnya setelah Eropa terbentuk menjadi benua kristiani, sementara "negeri-negeri seberang” merupakan dunia non-kristiani, kafir, perlu diselamatkan. Gagasan misi sebagai penyelamatan jiwa-jiwa yang berciri perorangan atau individual ini, di awal abad ke-20, pada era yang sama dengan munculnya pusat studi misi di Leuven, Belgia, diolah dan dikembangkan oleh pusat studi misi di Münster, Jerman, dengan tokohnya Rm. Joseph Schmidlin (Insero, 2007:118-119).

Dalam wacana misiologi, teologi plantatio Ecclesiae menolak pandangan bahwa tujuan misi adalah mempertobatkan jiwa-jiwa. Tugas misionaris tidak sekedar berciri personal-individual, tapi sosial-eklesial, dan institusional. Charles SJ menegaskan: 
"Misionaris bertugas bukan untuk menyelamatkan jiwa-jiwa, melainkan untuk mendirikan, di mana belum ada, saranakeselamatan yang biasa: atau Gereja yang kelihatan, dengan sumber ajarannya dan tujuh sakramennya yang mengalir deras... Menyelamatkan jiwa-jiwa, atau menanam Gereja... tidak ada yang lebih salah dari kekacauan ini.” (Dianich, 1987: 22).

Dalam perspektif ini, seiring dengan upaya-upaya perubahan sosial disemangati nilai-nilai Injil, pembentukan aspek institusional Gereja lokal menjadi hal sentral yang harus diupayakan oleh misionaris. Mgr. D. Catarzi SX, teolog plantatio Ecclesiae dari Italia mengatakan, tugas misionaris adalah memikirkan bagaimana menuntaskan, “di kaki katedral keuskupan, seorang putera, dari tanah air-angkatnya sendiri, mengikat mitra dan memegang tongkat gembala.” (Dianich, 1987: 22-23).

\subsection{Plantatio Ecclesiae dalam Konsep Misi Ad Gentes}

Ketika berbicara tentang pewartaan Injil dan penanaman Gereja sebagai tujuan misi, Ad Gentes art. 6 tidak eksplisit merujuk pada teolog plantatio Ecclesiae, tapi pada St. Thomas Aquinas dan para paus abad ke-20. Rupanya ini dimaksudkan untuk menegaskan bahwa gagasan plantatio Ecclesiae bukanlah ide yang sama sekali baru dalam visi Gereja tentang misi. Konsep ini sudah diwacanakan jauh sebelumnya oleh teolog utama abad pertengahan. Demikian pula, pada era modern konsep ini menjadi visi dasar di balik arahan para paus tentang misi, meskipun secara teknis mereka tidak menggunakan istilah plantatio Ecclesiae.

Merujuk Sententiae dan Summa Theologiae, catatan kaki no. 16 menyebutkan: "St. Thomas Aquinas sudah berbicara tentang tugas kerasulan menanam Gereja.” Selanjutnya disebut Paus Benediktus XV dengan surat apostolik Maximum Illud (1919), Pius XI dengan ensiklik Rerum Ecclesiae (1926), dan Pius XII dalam pidato kepada para direktur Karya Kepausan untuk Misi (1944, 1950, 1951) serta kepada para klerus pribumi (1948); juga Paus Pius XII dalam Ensiklik Evangelii Praecones (1951) dan Fidei Donum (1957). Juga dirujuk Paus Yohanes XXIII dalam ensiklik Princeps Pastorum (1959), dan Paus Paulus VI dari homili pada 18 Oktober 1964.

Dalam Maximum Illud, Paus Benediktus XV memberikan arahan bagi para misionaris di seluruh dunia tentang tujuan misi sebagai pembentukan Gerejagereja lokal, di manapun mereka mengemban tugas perutusan. Gereja-gereja itu harus memiliki tenaga-tenaga lokal bermutu, yang diperoleh melalui pembinaan bermutu, lengkap dan sempurna "seperti yang diberikan kepada para imam dari negara-negara maju”. Paus Benediktus XV mengatakan: 
"Akhirnya, mereka yang memimpin misi harus memiliki perhatian utama untuk menumbuhkan dan mendidik imamimam pribumi. Kebijakan itu sangat menjamin harapan bagi gereja-gereja baru. Imam pribumi, dengan memiliki asal-usul, karakter, mentalitas, aspirasi yang sama dengan penduduk setempat, sangat cocok untuk menanamkan iman ke dalam hati mereka karena, lebih daripada yang lain, tahu cara-cara mempengaruhi mereka....”

“... mutlak perlu bahwa imam pribumi hendaknya dilatih dan dididik secara memadai. Maka, tidaklah cukup suatu formasio sekadarnya dan hal-hal mendasar saja, asal bisa ditahbiskan menjadi imam. Formasio itu haruslah lengkap dan sempurna seperti yang diberikan kepada para imam dari negara-negara maju... jangan menyiapkan imam pribumi hanya sekadar untuk membantu imam-imam pendatang, dengan menjalankan pelayanan-pelayanan lebih rendah. Hendaknya ia dididik sedemikian rupa agar... akhirnya ia dapat menjalankan kepemimpinan Kristiani bagi umatnya dengan tepat.”

Lewat aneka dokumen, arahan Paus Benediktus XV direfleksikan, diulang dan ditegaskan kembali oleh para penerusnya. Masing-masing paus berbicara dengan cara dan berdasarkan situasi khas yang dihadapi pada masanya, hingga pada Konsili Vatikan II dihasilkan dekret Ad Gentes. Meski tidak menggunakan istilah plantatio Ecclesiae, semua dokumen universal tersebut jelas menggarisbawahi tugas mutlak para misionaris untuk membentuk Gereja lokal dalam perspektif plantatio Ecclesiae.

Dengan menggunakan istilah plantatio Ecclesiae dalam tujuan dan definisi misi, arah misi Gereja, yang telah dinyatakan oleh para paus era modern kerap dengan nada keprihatinan, mendapatkan penegasan dalam Konsili. Dengan pendefinisian ini, secara lebih umum dan mendasar, Konsili menyatakan bahwa misi Gereja sepanjang sejarah, sejak para rasul, adalah misi penanaman Gereja di tengah bangsa-bangsa.

Selain menyatakan bahwa penanaman Gereja merupakan tujuan misi, dan menjadikannya sebagai unsur definisinya, Ad Gentes juga menempatkan misi dalam bingkai pewartaan Injil. Disebutkan bahwa pewartaan Injil itu sendiri merupakan sarana utama dalam penanaman Gereja. Dengan pewartaan Injil itu “orang-orang yang lahir kembali berkat sabda Allah digabungkan pada Gereja melalui Baptis”.

Maka pewartaan Injil tidak boleh berada di ruang bebas atau di lahan kosong hingga dijadikan komoditi atau alat kepentingan. Aktivitas itu selalu berada dalam wewenang Gereja, dan pelaksanaannya diletakkan dalam bingkai 
eklesiologi misioner dalam perspektif penanaman Gereja, atau plantatio Ecclesiae.

\subsection{Plantatio Ecclesia dan Perspektif Misi Berkelanjutan}

Setelah membahas definisi dan tujuan misi dalam perspektif plantatio Ecclesiae, Ad Gentes art. 6 menjelaskan buah yang diharapkan dari "pewartaan Injil dan penanaman Gereja” pada komunitas lokal. Yaitu hadirnya Gereja partikular yang dewasa dan mandiri, yang mampu menghayati hidup kristiani dan menyumbangkan diri bagi Gereja dalam lingkup lebih luas. Dikatakan:

"Demikianlah dari benih sabda Allah tumbuhlah di mana-mana Gereja-gereja khusus pribumi yang cukup mantap, mempunyai daya-kekuatan mereka sendiri serta dewasa, dilengkapi secukupnya dengan Hirarki mereka sendiri dalam persatuan dengan Umat beriman, pun dengan upaya-upaya yang sesuai dengan watak-perangai mereka, untuk sepenuhnya menghayati hidup kristiani, dan untuk menyumbangkan bagian mereka demi manfaat seluruh Gereja.”

Ad Gentes art. 6 juga menggunakan istilah “penanaman” atau plantatio untuk berbicara tentang kondisi permulaan misi, yang disusul dengan kondisi selanjutnya, yaitu kondisi kebaharuan atau keremajaan. Setelah kondisi-kondisi itu tercapai, dan terbentuk Gereja-gereja lokal, "kegiatan misioner Gereja tidak berhenti”. Ditegaskan: “Gereja-gereja partikular yang sudah terbentuk bertugas melanjutkannya, dan mewartakan Injil kepada semua dan setiap orang, yang masih berada di luar.”

Jelas di sini terdapat penekanan lebih jauh. Terbentuknya hirarki Gereja lokal mutlak untuk dicapai dalam misi, tapi misi tidak berakhir dengan terbentuknya hirarki Gereja lokal. Justru, setelah terbentuknya Gereja lokal, misi memasuki tahap baru. "Gereja-gereja partikular yang sudah terbentuk bertugas melanjutkannya, dan mewartakan Injil kepada semua dan setiap orang, yang masih berada di luar.” Tahap baru, yaitu tahap "misi yang berkelanjutan” (ongoing mission), disertai pergeseran peran, dari misi oleh misionaris asing menjadi misi oleh Gereja lokal yang terbentuk.

Misi berkelanjutan ini dipertegas oleh Ad Gentes art. 6 dengan berbicara tentang keadaan yang mungkin terjadi jauh setelah Gereja lokal terbentuk. Dikatakan, jika dalam perkembangan nanti muncul "keadaan-keadaan yang sama sekali baru”, Gereja wajib mempertimbangkan, apakah “diperlukan kegiatan misioner lagi”. Atau, jika untuk sementara keadaan tidak memungkinkan untuk mewartakan Injil secara langsung, diperlukan "kesaksian akan cinta kasih dan kemurahan hati Kristus”, untuk "menyiapkan jalan bagi Tuhan, dan dengan cara tertentu menghadirkan-Nya”. 
Gagasan “misi berkelanjutan” (on-going mission) selaras dengan eklesiologi misioner Ad Gentes yang dinyatakan dalam kesadaran akan hakikat misioner Gereja. Menurut Ad Gentes art. 2: "Dari hakikatnya Gereja peziarah adalah misioner, karena ia sendiri berasal dari perutusan Putera dan perutusan Roh Kudus menurut Rencana Allah Bapa”. Maka ketika terbentuk Gereja lokal yang baru, komunitas baru ini sekaligus menyerap dan mengenakan hakikat misioner pada dirinya. Gereja lokal itu menjadi komunitas misionaris itu sendiri, bagi saudara-saudarinya sebangsa.

Menurut Ad Gentes art. 20, Gereja lokal yang terbentuk memiliki "kewajiban untuk menghadirkan Gereja semesta sesempurna mungkin". Gereja lokal atau partikular yang baru ini harus betul-betul menyadari "bahwa ia juga diutus kepada mereka yang belum beriman akan Kristus dan bersama dengannya menghuni daerah yang sama”. Kewajiban menghadirkan Gereja universal dan tugas misioner kepada saudara sebangsa ini ditempuh "melalui kesaksian hidup masing-masing anggota". Kesaksian hidup penting, agar "seluruh jemaatnya menjadi tanda yang menunjukkan Kristus kepada mereka”. Selain itu diperlukan pewartaan langsung, "supaya Injil mencapai semua orang”. Tugas ini berlaku bagi uskup, imam, religius dan awam.

Tugas misi itu melekat dan tidak pernah berhenti, apapun situasi yang terjadi di masa depan. Termasuk ketika terjadi situasi khusus, karena "keadaankeadaan yang sama sekali baru”, atau ketika pewartaan Injil tidak bisa dilakukan secara langsung. Sebagai Gereja baru, komunitas perlu melatih diri dan mengembangkan kemampuan membaca tanda-tanda zaman, berinovasi dalam menjalankan misi yang berkelanjutan. Harus bertekun dan bersabar "menyiapkan jalan bagi Tuhan” melalui kesaksian hidup, khususnya ketika pewartaan Injil secara langsung sulit untuk dilakukan.

Pentingnya "misi yang berkelanjutan” diperjelas dengan pembedaan yang tegas antara misi dan pastoral: "kegiatan misioner di antara bangsa-bangsa berlainan dengan kegiatan pastoral terhadap Umat beriman”. Kegiatan misioner dilihat sebagai kegiatan "keluar Gereja”, sementara kegiatan pastoral merupakan kegiatan "dalam Gereja”. Kegiatan misioner juga dibedakan dari ekumenisme, yakni “usaha-usaha yang ditempuh untuk meningkatkan kesatuan umat kristiani”.

Meskipun kegiatan pastoral dan ekumenisme dibedakan dari kegiatan misioner, tetapi keduanya "berhubungan erat sekali dengan kegiatan misioner Gereja”. Juga kegiatan ekumenisme terkait erat sekali, sebab “perpecahan Umat kristen merugikan kepentingan amat suci, yakni pewartaan Injil kepada segala makhluk, dan bagi banyak orang menutup pintu untuk memasuki iman.” 


\subsection{Paroki Misioner dalam Ardas 2020-2030}

Menurut Ardas 2020-2030 Penjelasan Butir B.11, sebagai “jemaat tertentu kaum beriman kristiani yang dibentuk secara tetap dalam Gereja partikular”, paroki adalah basis persekutuan umat yang utama di keuskupan. Sedangkan di tingkat paroki, basis persekutuan yang utama adalah lingkungan, sebagai "akar" yang bersifat "komuniter dan signifikan" bagi paroki. Lingkungan ini diutus “dengan sadar menghadirkan diri sebagai suatu jemaat yang relevan” di tengah masyarakat.

Paroki berbasis lingkungan, yang "signifikan” bagi paroki dan "relevan” bagi masyarakat, dipanggil untuk mendewasakan diri "dengan cara mengusahakan kedewasaan iman umat”. Kedewasaan paroki menjadi prioritas “agar murid-murid Kristus dapat mewujudkan persekutuan yang semakin dewasa dalam iman, guyub, penuh pelayanan dan misioner sesuai dengan semangat Ardas”. Wujud kedewasaan tampak jika umat mempunyai "rasa memiliki” (sense of belonging, rasa handarbeni) terhadap komunitas lebih besar: "setiap warga terhadap lingkungan atau kelompoknya, setiap lingkungan atau kelompok terhadap paroki, dan paroki terhadap keuskupan”.

Gambaran kedewasaan paroki dan warganya, dalam cita-cita Ardas 20202030, bukan merupakan tujuan akhir. Yang ingin diwujudkan lebih lanjut lewat kedewasaan itu adalah penanaman Gereja. Penjelasan butir B.12. menyatakan, "kehadiran dan peran paroki yang semakin dewasa sangat penting untuk mewujudkan 'penanaman Gereja' (Plantatio Ecclesiae) di wilayah Keuskupan Surabaya”.

Kepedulian paroki serta warganya untuk mewujudkan penanaman Gereja (plantatio Ecclesiae) merupakan "salah satu ukuran kedewasaan paroki”. lingkup kepedulian paroki yang dewasa menurut Ardas 2020-2030 tidak terbatas pada wilayah paroki itu sendiri, tapi "baik di wilayahnya sendiri maupun di wilayahwilayah lain yang paling membutuhkan”. Kepedulian itu didasari "semangat solidaritas Keuskupan sebagai satu persekutuan”. Demi terwujudnya solidaritas antarparoki dalam plantatio Ecclesiae, "setiap paroki dipanggil mengembangkan solidaritas antarparoki untuk meneguhkan 'anggota tubuh' yang lemah, sakit, terlantar, dan terbelenggu”.

Selain kepedulian yang bersifat lintas batas, kedewasaan paroki dalam plantatio Ecclesiae juga dikaitkan dengan semangat pemekaran paroki itu sendiri. Dikatakan, paroki-paroki “dipanggil untuk mengembangkan diri dan lebih jauh memekarkan diri demi semakin efektifnya penggembalaan yang membangun persekutuan".

Lewat paroki-paroki yang dewasa, berkepedulian dalam semangat misioner dan memekarkan diri, dengan warga yang punya "rasa memiliki" terhadap komunitas lebih besar, tujuan keberadaan Gereja di masyarakat dalam 
rangka plantatio Ecclesiae akan tercapai. "Dengan cara ini diharapkan kehadiran Gereja di tengah masyarakat dapat semakin dirasakan dan berdampak positif bagi tugas perutusannya”.

Penegasan bahwa plantatio Ecclesiae merupakan tugas paroki (B.12.) disertai arahan untuk mewujudkan plantatio Ecclesiae dengan mempersiapkan para pekerja misi (E.3.). Butir “siap sedia menjadi pekerja misi” dibuka dengan pernyataan:

Gereja memanggil setiap orang yang telah dibaptis ambil bagian dan menjadi pekerja Allah. Oleh Yesus pekerja Allah ini disebut "pekerja untuk tuaian”. Ia bersabda, "Tuaian memang banyak, tetapi pekerja sedikit. Karena itu mintalah kepada Tuan yang empunya tuaian, supaya Ia mengirimkan pekerja-pekerja untuk tuaian itu” (Mat 9:37-38).

Yesus juga menyebut pekerja Allah ini sebagai "penjala manusia”. Kata-Nya, "Jangan takut, mulai dari sekarang engkau akan menjala manusia” (Luk 5:10). Para pekerja Allah diutus untuk ambil bagian di dalam karya misi bagi keselamatan jiwajiwa manusia terutama mereka yang belum mengenal Kristus.

Para pekerja misi disebut “pekerja Allah” yang bekerja untuk tuaian-Nya. Mereka disebut "penjala manusia”, untuk menyatakan bahwa mereka diutus untuk ambil bagian dalam karya misi "bagi jiwa-jiwa manusia”. Mereka bekerja untuk tuaian “jiwa-jiwa”, terutama "mereka yang belum mengenal Kristus”.

Di satu sisi, hadirnya pekerja-pekerja Allah merupakan hal penting yang perlu dimohon, karena "tuaian memang banyak, tetapi pekerja sedikit". Di sisi lain, setiap orang yang telah dibaptis secara umum dipanggil untuk "ambil bagian dan menjadi pekerja Allah”. Mereka hendaknya menyediakan diri menjadi pekerja misi.

Selain panggilan umum menjadi pekerja misi, yang berlaku bagi semua orang yang telah dibaptis, Penjelasan Butir E.3. juga berbicara tentang upayaupaya khusus untuk membina para pekerja misi. Dikatakan: "Untuk mewujudkan hal ini, program pembinaan pekerja-pekerja misi perlu dikembangkan”.

Juga dikehendaki agar penanaman Gereja (plantatio Ecclesiae) dibangkitkan, “di daerah/ wilayah di mana Kristus belum dikenal”. Disadari, ada kalanya tantangan iman dihadapi oleh Gereja sendiri, sehingga penanaman Gereja diharapkan juga menjangkau "daerah/wilayah di mana iman kepada-Nya telah memudar”. Dalam rangka itu, kepada pekerja-pekerja misi "Gereja mendorong untuk terus melaksanakan evangelisasi baru di zaman ini”. Di sini tampak adanya kebutuhan untuk membina ketrampilan khusus dalam membaca dan menyiasati tanda-tanda zaman. 
Di sini tampak bahwa program pembinaan pekerja misi perlu dikembangkan sedemikian rupa untuk membantu agar para pekerja misi mampu membaca situasi dan tantangan yang bisa berbeda-beda untuk setiap wilayah dan keadaan. Selain berbagai ketrampilan yang bersifat praktis dalam karya misi, juga dibutuhkan ketrampilan analisis terhadap situasi-kondisi masyarakat maupun Gereja sendiri.

Dengan Penjelasan Butir B.12., dilengkapi dengan Butir E.3., secara garis besar tergambarkan arah misioner Keuskupan Surabaya yang dikehendaki Ardas 2020-2030 dalam perspektif plantatio Ecclesiae. Dari perspektif sejarah misi di Keuskupan, kiranya arah ini dapat dibaca dalam kerangka suatu "misi yang berkelanjutan”.

Sebagai suatu Gereja lokal yang mandiri, subjek utama misi Keuskupan adalah paroki. Untuk menjadi subjek misi yang baik, paroki perlu mendewasakan diri, menjadi paroki yang peduli pada kebutuhan misi, baik di wilayahnya sendiri maupun di wilayah-wilayah lain di Keuskupan. Paroki perlu mendewasakan para warganya, agar mempunyai “rasa memiliki” terhadap komunitas yang lebih besar.

Semangat sebagai "pekerja misi" perlu ditumbuhkan pada seluruh umat atas dasar rahmat baptis. Di sisi lain, juga perlu dipersiapkan tenaga-tenaga khusus. Maka perlu diadakan program-program pembinaan agar diperoleh pekerja-pekerja misi, yang “siap-sedia” dan memiliki ketrampilan yang diperlukan untuk karya misi, sesuai situasi atau kebutuhan khusus paroki, dan secara umum di keuskupan.

\section{IMPLEMENTASI}

Hirarki Keuskupan Surabaya didirikan pada tahun 1961. Sudah 60 tahun usaha menjadi Gereja mandiri terus dilakukan. Melalui Mupas I tahun 2009, dan terlebih Mupas II tahun 2019, ditetapkan Arah menjadi Gereja persekutuan yang misioner. Arah ini senada dengan gambaran pembentukan Gereja pribumi dalam visi plantatio Ecclesiae, baik yang dinyatakan oleh para teolognya, maupun oleh para Paus. Secara khusus, arah ini senada dengan Konsili Vatikan II dalam dekret Ad Gentes, yang menegaskan hakikat misioner Gereja bersumber dari misi Allah Tritunggal, dan tugas “misi yang berkelanjutan” bagi Gereja lokal yang dihasilkan oleh karya misi.

Dengan arah ini, aneka potensi dan sumber daya Keuskupan perlu dikelola dan dikembangkan untuk membentuk "persekutuan murid-murid Kristus” yang misioner, seperti dikehendaki oleh Butir Penjelasan E.3. Ardas 2020-2030. Dengan penekanan pada pentingnya peran paroki dan dimensi formatio pekerja misi, terdapat beberapa butir penting untuk dijadikan pegangan dan prioritas dalam upaya implementasi. 
Pertama, perlunya pembedaan dan dengan demikian, sinergi, antara karya pastoral dan karya misi. Keduanya di satu sisi terkait erat, tapi di sisi lain memiliki dimensi-dimensi berbeda. Juga penting melihat aspek ekumenis pada keduanya, baik terkait dengan komunitas-komunitas gerejawi umumnya maupun dengan individu yang dibaptis di dalamnya. Pembedaan dan sinergi di antara karya-karya ini diperlukan agar masing-masing karya berjalan sesuai dengan tujuan khasnya.

Kedua, perlunya mencermati perangkat karya yang mendukung misi. Dalam struktur karya Keuskupan, terdapat sejumlah perangkat karya yang terkait erat dengan tujuan misi, baik pada Pusat Pastoral (misalnya: Komisi Karya Misioner, Komisi HAK) maupun di luarnya (berbagai karya pendidikan/sekolah, kesehatan dan sosial, serta aneka kelompok dan kerasulan kategorial), yang dibutuhkan adalah fungsi yang mampu mensinergikan berbagai karya tersebut dari perspektif misi.

Ketiga, perlunya mencermati perangkat formatio untuk menyiapkan pekerja misi. Selain sinergi di antara berbagai karya dalam perspektif misi, dibutuhkan pula sinergi di bidang pembinaan. Dari perspektif pembinaan, upaya sinergi melibatkan Pusat Pastoral (komisi-komisi di bidang sumber dan formatio) maupun di luarnya (sekolah-sekolah katolik, Institut Teologi Yohanes Maria Vianney/IMAVI, STKIP Widya Yuwana, SEP/KEP dan berbagai kursus teologi yang tumbuh di Keuskupan).

Keempat, perlunya menegaskan subjek-subjek misi. Ardas 2020-2030 Butir Penjelasan B.11. dan B.12. menghendaki terbentuknya paroki yang dewasa sebagai subjek utama pengemban tugas misi penanaman Gereja (plantatio Ecclesiae), maka strategi karya dan pembinaan misi Keuskupan haruslah berbasis paroki, dan di tingkat paroki berbasis lingkungan, dan dalam semuanya berfokus pada keluarga, karena keluarga adalah "sekolah", locus (tempat) dan fokus pembinaan misi yang utama.

Kelima, perlunya strategi misi sejalan dengan Ardas 2020-2030. Karya misi merupakan karya berjangka panjang dan berdimensi khusus, maka perlu disusun strategi, pentahapan, menyertakan aspek sosio-ekonomi-politik-budaya, termasuk penguasaan bahasa-bahasa lokal, khususnya Jawa dan Mandarin sebagai sarana komunikasi dan masuk ke dalam budaya yang hidup di masyarakat yang menggunakannya.

Keenam, perlunya mencermati unsur-unsur penunjang keilmuan dan aspek kerjasama dengan lembaga-lembaga sevisi. Seperti karya pastoral membutuhkan data dan penelitian, begitu pula karya misi juga membutuhkan hal yang sama. Untuk itu, kerjasama dan sinergi di bidang ini dengan lembaga-lembaga pendidikan dan penelitian harus diupayakan. Begitu pula kerjasama dan sinergi secara umum dengan lembaga dalam Keuskupan maupun di luar Keuskupan, juga 
di luar negeri, dalam hal-hal penunjang yang dibutuhkan untuk pengembangan misi.

\section{KESIMPULAN}

Dalam perjalanan Keuskupan Surabaya sendiri, istilah Plantatio Ecclesia telah diwacanakan oleh Mgr. V. Sutikno Wisaksono dan Rm. A. Tribudi Utomo sejak tahun 2013, menjelang pendirian paroki Mojorejo dan Resapombo. Istilah itu muncul dilatarbelakangi keinginan untuk menguatkan dan menghidupkan kembali kehadiran Gereja di wilayah pedesaan di Keuskupan Surabaya, yang dikhawatirkan mengalami kepunahan. Wilayah-wilayah seperti itu perlu didampingi secara langsung oleh pastor (ditunggoni romo), maka perlu didirikan paroki-paroki di pedesaan.

Dengan demikian, istilah plantatio Ecclesiae tidak digunakan sepenuhnya dalam pengertian awal misi, karena mengandung unsur pastoral, berkenaan dengan komunitas yang telah terbentuk, namun karena situasi membutuhkan perhatian khusus. Di sisi lain, istilah ini juga diartikan mengembangkan (mencangkok) tanaman yang sudah ada di daerah yang masih kosong. Bagaimanapun, dalam konteks lebih besar, terlihat bahwa penggunaan istilah ini terkait dengan kondisi yang membutuhkan semangat "misi yang berkelanjutan” sebagaimana dikatakan dalam Ad Gentes.

Bagi Keuskupan Surabaya, upaya menghadirkan keselamatan bagi para bangsa, dalam hal ini di wilayah Keuskupan, merupakan tugas yang melekat karena jatidirinya sebagai persekutuan murid-murid Kristus yang misioner, berdasar pada misi Allah Tritunggal bagi dunia. Tugas itu dijalankan olehnya dengan cara mewartakan Injil dan menghadirkan dirinya, bukan hanya bagi orang yang telah dibaptis, melainkan bagi siapa saja yang terpanggil untuk mengenal dan mengasihi Allah secara lebih dalam melalui Yesus Kristus, Sabda yang menjadi manusia.

Pewartaan Injil dan kehadiran Gereja yang berciri misioner ini menjadi tugas yang terus-menerus, berkelanjutan, juga ketika sebagai Gereja lokal ia telah terbentuk. Namun tugas itu kini merupakan tanggung jawab para warga Gereja lokal itu sendiri, untuk menghadirkan Injil dan nilai-nilai kerajaan Allah bagi sesama di sekitarnya. Dalam kerangka ini, kesadaran mengenai tugas misioner menjadi prioritas untuk ditumbuhkan, yang harus disusul dengan pembinaan untuk tenaga-tenaga khusus. Dengan cara itu, Gereja selain memiliki makna yang istimewa bagi dirinya, juga sungguh-sungguh relevan bagi keselamatan dunia di sekitarnya. 


\section{DAFTAR PUSTAKA}

Benediktus XV, Paus, 1919, Surat Apostolik Maximum Illud, dalam Departemen Dokumentasi dan Penerangan KWI, Seri Dokumen Gerejawi No. 108, 2019. Jakarta: Penerbit Obor.

Comby, Jean, 1994, Duemila anni di evangelizzazione, Turin: Società Editrice Internazionale.

Dianich, Severino, 1987, Chiesa in missione. Per una ecclesiologia dinamica. Cinisello Balsamo (Milan): San Paolo Edizioni.

Insero, Walter, 2007, La chiesa è "missionaria per sua natura” (AG 2). Origine e contenuto dell'affermazione conciliare e la sua recezione nel dopo Concilio. Roma: Editrice Pontificia Università Gregoriana.

Keuskupan Surabaya, 2019, Seri Mupas 2019, Buku 1, Arah Dasar Keuskupan Surabaya Tahun 2020-2030.

Konsili Vatikan II, 1965, "Dekrit tentang Kegiatan Misioner Gereja Kepada para Bangsa (Ad Gentes)”, dalam Departemen Dokumentasi dan Penerangan KWI, 1993, Dokumen Konsili Vatikan II. Jakarta: Penerbit Obor.

Metzler, Josef, 1990, Dalle missioni alle chiese locali. Cinisello Balsamo (Milan): Edizioni Paoline.

Prudhomme, Claude, 2007, Missioni Cristiane e Colonialismo. Milan: Jaca Book.

Tai-Fai, Savio Hon, tanpa tahun, "New Evangelization in an Asian Context. Towards a Renewed Missionary Enthusiasm”. Makalah disampaikan dalam Seminar untuk uskup, imam dan formator, oleh FABC Office of Clergy, Proclaiming the Joy of the Gospel as Renewed Evangelizers in Asia. Pattaya, Thailand.

Tan, Jonathan Y., 2019, “From 'Ad Gentes’ to 'Active Integral Evangelization': The Reception of Vatican II's Mission Theology in Asia”, dalam Asia Pacific Mission Studies 1.1 (2019). 35-68 (Aslinya terbit dalam East Asian Pastoral Review 50, no. 3 [2013]: 217-250). 